\title{
Genetic Diversity among Faba Bean Hybrids in Relation with Heterosis Using Molecular and Agronomic Data
}

\author{
Amal M. Abd EL-Mageed \\ Botany Department, Faculty of Agriculture, Suez Canal University, 41522 Ismailia, \\ Egypt.
}

\begin{abstract}
CENETIC diversity was examined in relation to heterosis. Five Egyptian faba bean cultivars were crossed in a full diallel mating system to produce twenty hybrids. The multivariate analysis of diversity based on six characters related to productivity indicated the existence of considered genetic diversity and showed genotypes into five clusters by two methods analysis of genetic distances based on RAPD analysis and Euclidean distances based on mean values of studied agronomy traits. Parents and their F1 hybrids were distributed into different clusters. Results of the RAPD technique by using five primers showed a great extent of significant variations with $67.59 \%$ polymorphism percent and a high number of unique bands. Sakha 1 and Giza 843 cultivars have a good effect on most studied traits in their hybrids. H13, H17 and H18 are a superiority hybrids; it has high positive significant values of heterosis percentage over mid parents for all yield and yield components traits. While H19 and $\mathrm{H} 20$ hybrids have positive significant heterosis for all studied traits except 100 seeds weight.
\end{abstract}

Keywords: Genetic diversity, Faba bean, Hybrids, Yield traits, RAPD, Heterosis.

\section{Introduction:}

Vicia faba L. is the most important nutrient crop in Egypt and many countries around the world. Seeds of faba bean contain high percent of protein and carbohydrates. Seeds are used in variety forms in different meals in developing countries. Faba bean crop belong to leguminous family which have 12 pair of chromosomes. Molecular breeding strategies that integrate the latest innovations in genetics and genomics with traditional breeding strategies have many potential applications for future faba bean cultivar development (Moose \& Mumm, 2008). Genetic diversity is considered the indispensable base for achieving the diverse aims of plant genetic improvement (Tiwari, 2017). Different molecular marker techniques are used in faba bean to detect the genetic variability between different genotypes like RFLP, SSR, AFLP and RAPD. The broad applicability of molecular tools in conventional faba bean breeding will remain a topic of debate (Goodman, 2004). Molecular characterization of genetic diversity by RAPD markers allow to understand the genetic relationship among the elite lines and aid to make the choice of superior parents for hybridization of faba bean and onion (Tanttawi et al., 2007; Vajire et al., 2017 and Dora et al., 2017). RAPD analysis was assisting faba bean breeders as index to developed genotypes with varied genetic background in order to sustainability in faba production in country (Tahir, 2015). Precise information on the nature and degree of genetic diversity would help in choosing the right parents for hybridization to obtain heterosis (Hayman, 1958 and Obiadalla-Ali et al., 2015). Several studies have tried to relate genetic diversity with hybrid performance. Obtaining higher heterotic expression in $\mathrm{F}_{1 \mathrm{~s}}$ and broad spectrum of variability in segregating population, were obtained from increasing the genetic diversity between parents (Shekhawat et al., 2001 and Johnson et al., 2015). Significant variations for agro-morphological traits; plant height, branchs number, pods number, seeds number and seed yield/plant of faba genotypes indicated to significant correlation between agro-morphological traits and results of AFLP technique marker of DNA (Ammar et al., 2015) and also for RAPD technique marker (Dora et al., 2017). Seed characters of faba bean are contributed markedly and significantly from their own genes to the genetic variation (Dieckmann \& 
Link, 2010). Several factors like environmental conditions and genetics factors are affected on faba bean in Egypt. So, the using of molecular markers like RAPD help breeder to select the best genotypes of faba bean in short time (Abdel Sattar and El-Mouhamady, 2012 and Vajire et al., 2017).

Therefore, this study was undertaken to determine the nature and magnitude of genetic diversity among a set of Egyptian faba bean genotypes and their $\mathrm{F}_{1}$ hybrids resulting from a diallel mating system as determined from agronomic and molecular data.The study was also extended to detect any existed relationship between genetic diversity and heterosis in faba bean (Vicifaba L.)

\section{Materials and Methods}

Five faba bean genotypes namely; Sakha 1 (P1) - Sakha 3 (P2) - Maser 3 (P3) - Giza 3 (P4) and Giza 843 (P5) are obtained from Agriculture Research Center, Giza, Egypt. Seeds of cultivars were sowed at 2013/2014 winter in the Experimental Farm of Faculty of Agriculture, Suez Canal University. A diallel mating system were carried out among these parents (full diallel) to obtain twenty hybrids: H1: Sakha 1 X Sakh 3, H2: Sakha 1 X Misr 3, H3: Sakha 1 X Giza 3, H4: Sakha 1 X Giza 843, H5: Sakha 3 X Sakh 1, H6: Sakha 3 X Misr 3, H7: Sakha 3 X Giza 3, H8: Sakha 3 X Giza 843, H9: Misr 3 X Sakh 1, H10: Misr 3 X Sakh 3, H11: Misr 3 X Giza 3, H12: Misr 3 X Giza 843, H13: Giza 3 X Sakh 1, H14: Giza 3 X Sakh 3, H15: Giza 3 X Misr 3, H16: Giza 3 X Giza 843, H17: Giza 843 X Sakh 1, H18: Giza 843 X Sakh 3, H19: Giza 843 X Misr 3 and H20: Giza 843 X Giza 3.

Seeds of the five parents and their $\mathrm{F}_{1}$ hybrids were sowed in 2014/2015 winter in a Randomized Block Design within three replications. Plant samples were taken at flowering stage and harvest stage to measure:

\section{The agronomic traits}

Plant height $(\mathrm{cm})$, branches number/plant, pods number/plant, seeds number/pods, pods weight/plant $(\mathrm{g})$, seed weight/plant $(\mathrm{g})$ and 100 seed weight $(\mathrm{g})$ were measured.

\section{The molecular data}

They were derived from a RAPD-PCR procedure. It was carried in Bio technology laboratory, Faculty of Agriculture, Suez Canal University.

\section{DNA extraction}

The third leaf from apical of plants was taken as a fresh leaf samples of five faba bean cultivars and their twenty hybrids plants at flowering stage, to extract Genomic DNA by using DNA preparation kit, using manual protocol cetyl tri methyl ammonium bromide (CTAB) protocol according to Poresbski et al. (1997).

Five selective primers are used to survey the genomes of studied genotypes (Table 1).

TABLE 1. Name of the five primers and their sequences.

\begin{tabular}{lc}
\hline Primer name & \multicolumn{1}{c}{ Primer sequences } \\
\hline OPP1 & 5'-GTAGCACTCC -3' \\
OPA7 & 5'-GAAACGGGTG-3' \\
OP Q1 & 5'- GGGACGATGG -3' \\
OP T8 & 5'-AACGGCGACA -3' \\
OP N4 & 5'- GACCGACCCA -3' \\
\hline
\end{tabular}

PCR reaction

Consist of $12.5 \mu \mathrm{l}$ master mix, $2 \mu \mathrm{l}$ DNA template $(20 \mathrm{ng} / \mu \mathrm{l}), 2 \mu \mathrm{l}$ primer (20 pmole), $8.5 \mu \mathrm{l}$ Milli-Q water and reached total volume to $25 \mu \mathrm{l}$.

\section{Thermal profile}

Five min at $94^{\circ} \mathrm{C}, 40$ Cycles $\left(30 \mathrm{sec}\right.$ at $94^{\circ} \mathrm{C}$, $30 \mathrm{sec}$ at $30^{\circ} \mathrm{C}, 30 \mathrm{~min}$ at $72^{\circ} \mathrm{C}$ ) and $7 \mathrm{~min}$ at $72^{\circ} \mathrm{C}$. Gel preparation: $1 \%$ Agarose gel in $1 \mathrm{X}$ TAE buffer was used.

Samples Key on gel for each primer (M)

DNA ladder, P1, P2, P3, P4, P5, H1, H2, H3, H4, H5, H6, H7 ,H8, H9, H10, H11, H12, H13, H15, H17, H18, H19 and H20 Key of these cultivars and hybrids illustrated in the first part of materials and methods.

\section{Gel analysis}

Photos were captured using G:BOX documentation system (SYNGENE) and the analysis was done using a Gene tools program version 4.03.05.0 from SynGene.

A Microsoft Excel file was prepared for scoring the data as ' 1 ' for presented and ' 0 ' for absented DNA bands of every genotype for computed similarity and genetic distance. 
Dendrogram was constructed using Jaccard similarity coefficient (Jaccard, 1908) and the unweighted pair group method with arithmetic average (UPGMA) (Sneath \& Sokal, 1973), cluster analysis and dendrogram construction were performed with SPSS (1995).

\section{Statistical analysis of data}

The heterotic effects of $\mathrm{F}_{1}{ }^{\mathrm{s}}$ were estimated as percentage over mid parents as follows:

Mid-parent heterosis $=\left(\mathrm{F}_{1}-\mathrm{MP}\right) \times 100 / \mathrm{MP}$

where: $F_{1}=$ Mean of $F_{1}$ cross, $M P=$ Mean of mid parents

Diversity analysis of means of all studied

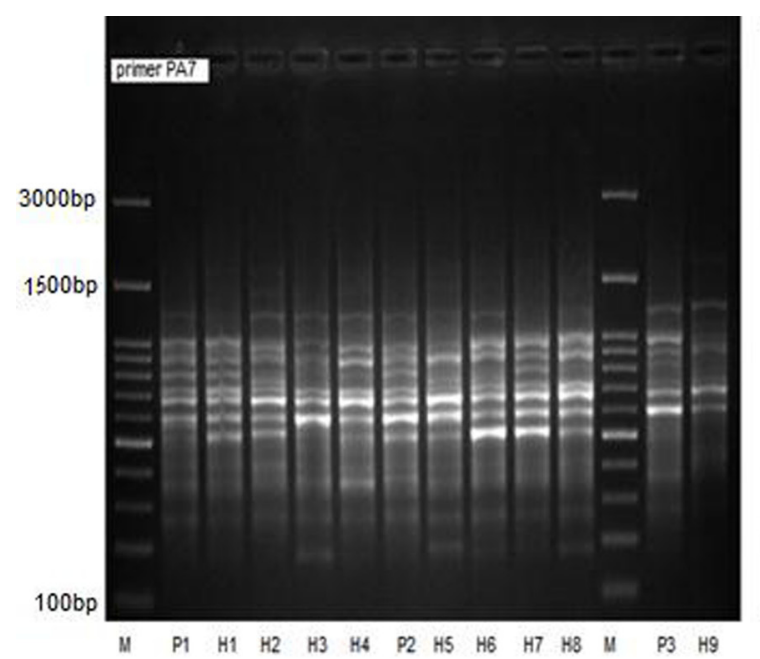

agronomic traits and molecular RAPD data were analyzed based on the Euclidean distances using the method proposed by Laghetti et al. (2008).

\section{$\underline{\text { Results and Discussion }}$}

\section{RAPD analysis}

Based on the data from the preliminary study RAPD analysis was performed (Photos 1, 2, 3, 4 and 5). Five primers were selected to carry the reactions (Table 1). Their amplification products with faba bean genomes showed generated banding patterns presented in Table 2. Molecular tools can be used to understand the gene action and breeding value at various loci distributed across the genomes (Johnson \& Mccuddin, 2009).

Photo 1. RAPD Amplified banding pattern of five cultivars of faba bean and their hybrids by using primers.
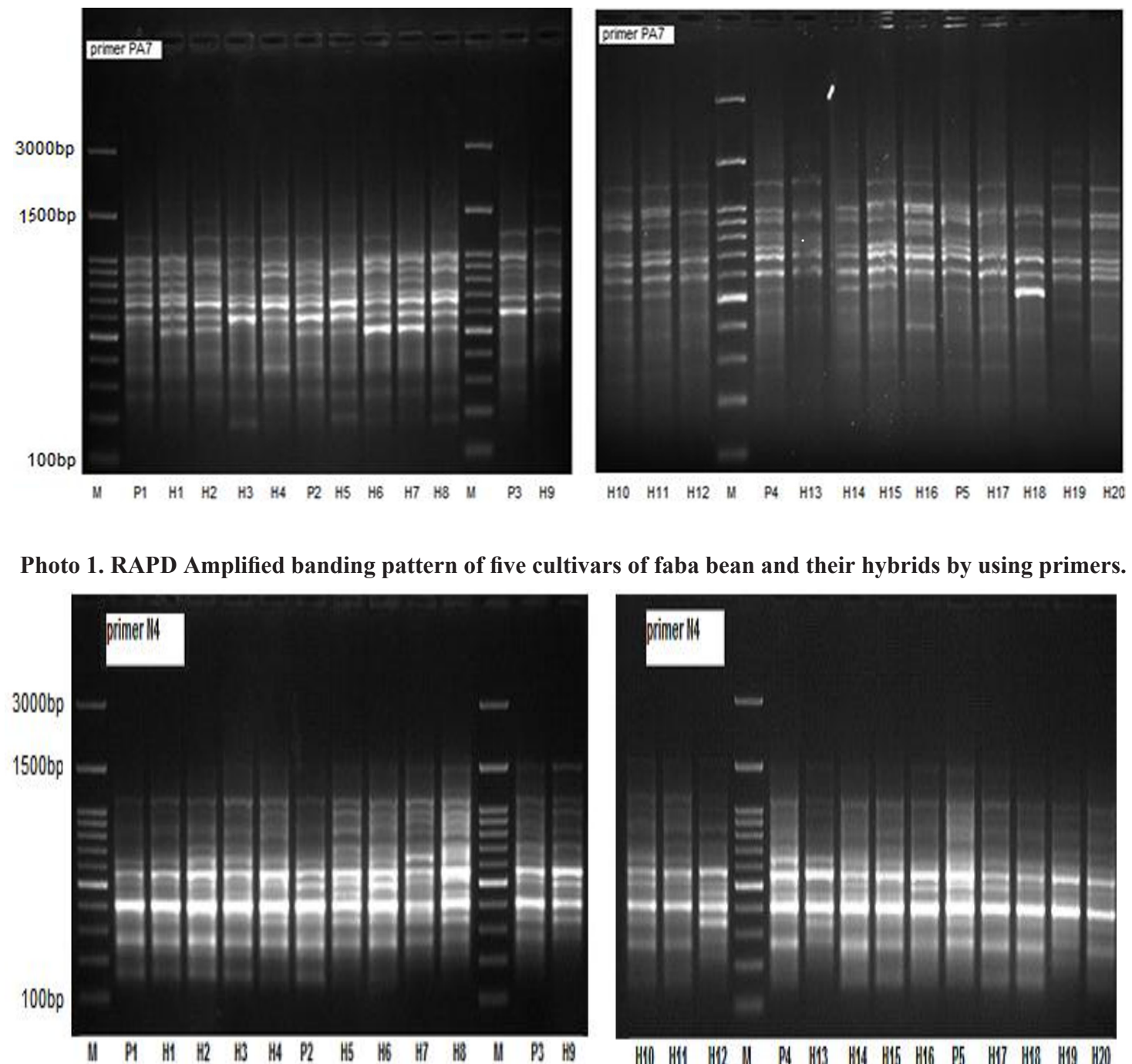

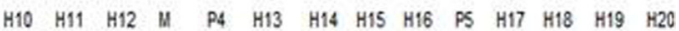

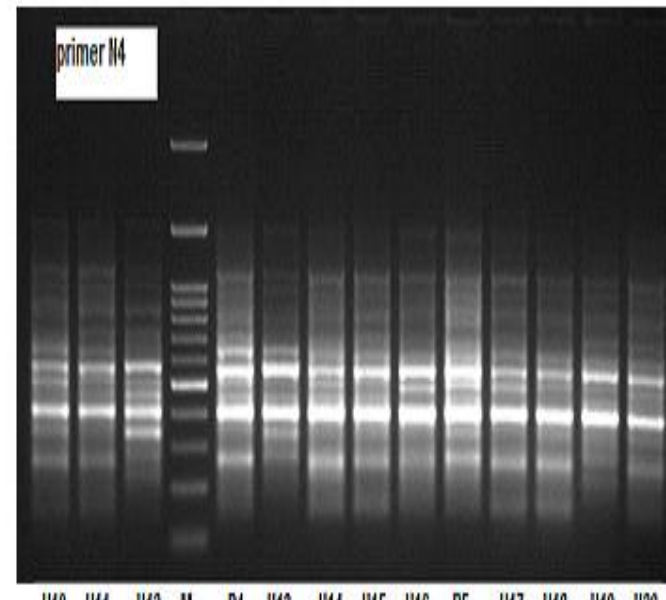

HIO HII HII II

Photo 2. RAPD amplified banding pattern of five cultivars of faba bean and their hybrids by using primer N4. 


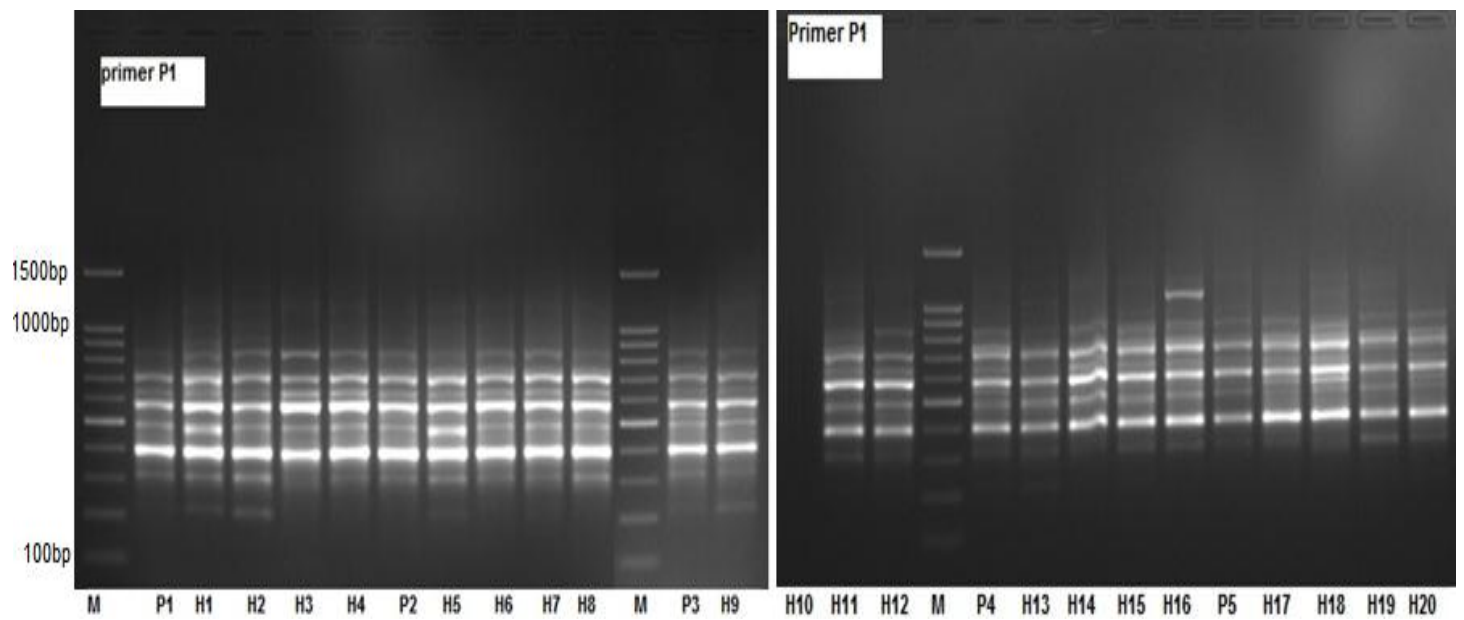

Photo 3. RAPD Amplified banding pattern of Five cultivars of faba bean and their hybrids by using primer P1.
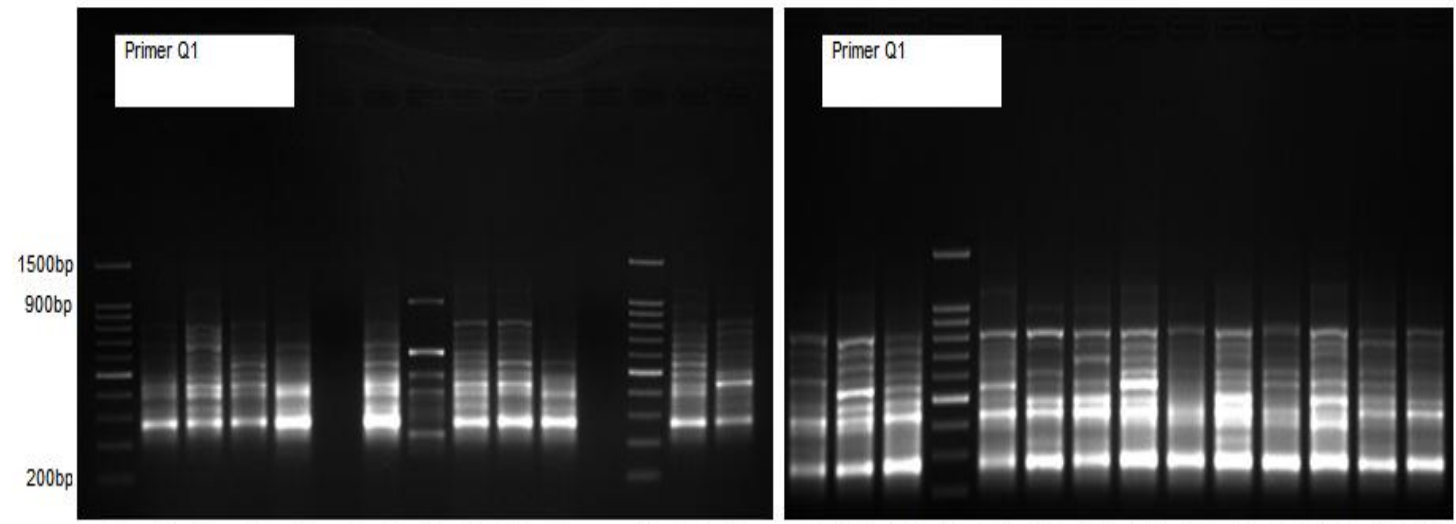

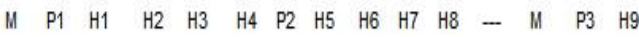

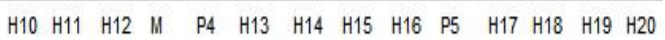

Photo 4. RAPD amplified banding pattern of five cultivars of faba bean and their hybrids by using primer Q1.
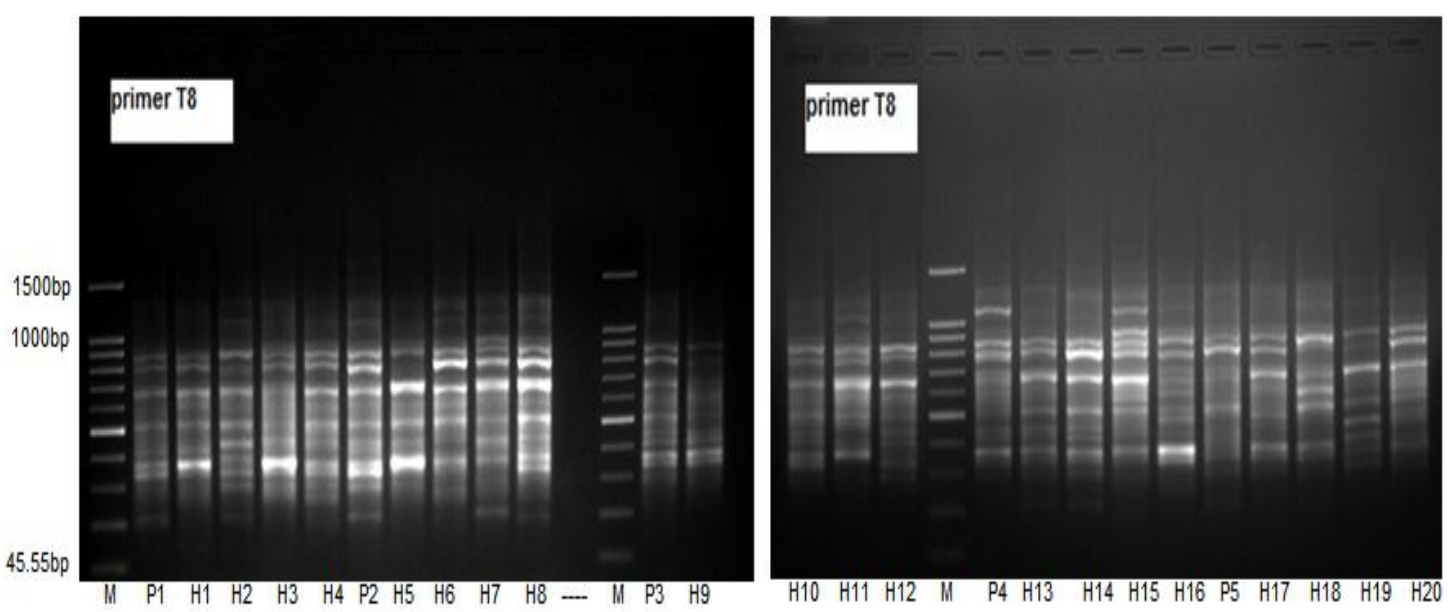

Photo 5. RAPD amplified banding pattern of five cultivars of faba bean and their hybrids by using primer T8. 
TABLE 2. Number of generated bands by using five primers and the polymorphism percent.

\begin{tabular}{lccccc}
\hline Primer & Bands number & $\begin{array}{c}\text { Unique } \\
\text { bands }\end{array}$ & $\begin{array}{c}\text { Polymorphic loci } \\
\text { number }\end{array}$ & Band marker size & Polymorphic\% \\
\hline OP-1 & 79 & 29 & 50 & $(100-1500 \mathrm{bp})$ & 63.29 \\
T8 & 85 & 25 & 60 & $(45.55-1500 \mathrm{bp}$ & 70.58 \\
N4 & 65 & 22 & 43 & $(100-3000 \mathrm{bp})$ & 66.5 \\
Q1 & 55 & 17 & 38 & $(100-1500 \mathrm{bp})$ & 63.15 \\
A7 & 90 & 23 & 67 & $(100-3000 \mathrm{bp})$ & 74.44 \\
Total & 374 bands & & & & 67.59 \\
Mean & 74.8 & & & & \\
\hline
\end{tabular}

Polymorphism percentage ranged from 63.15 to $74.44 \%$ with average 67.59 . The total numbers of bands generated from these reactions of the five primers were 374 bands, with an average 74.8 bands per primer. Results were in harmony with those obtained by Abdel Sattar \& ElMouhamady (2012), Khaled et al. (2014) Yahia et al. (2014) and Obiadalla-Ali et al. (2015), who reported that the percentage of polymorphic bands detected ranged from $33 \%$ to $100 \%$ with an average of $66.47 \%$ and the average of amplified bands was 5.42 polymorphic bands per primer. Fifty four amplified fragments with sizes ranged from $113 \mathrm{bp}$ to $1647 \mathrm{bp}$ were obtained with an average of 10.8 loci per primer and the polymorphism percentage ranged from $50 \%$ to $100 \%$ with an average $81 \%$ (Dora et al., 2017) and $86.9 \%$ polymorphism obtained by Alghamdi (2009). While; $53.57 \%$ polymorphism percent and 140 bands with an average 7.77 bands per primer were obtained by Tahir (2015). 94 DNA fragments were detected by using 11 RAPD markers with an average of 8.54 loci for each primer and sizes ranged from 160 to $1370 \mathrm{bp}$ were obtained by Basheer-Salimia et al. (2013). These differences may due to the type of cultivars and hybrids and/or the sequences of selected primers.

Genetic distances among faba bean parents and their hybrids based on the results of using RAPD markers were ranged from 0.34 to 0.84 (Table 3). The highest genetic distance found between H15 hybrid and all studied parents and some hybrids especially $\mathrm{H} 5, \mathrm{H} 10, \mathrm{H} 11$ and H12. So the hybridization process was carried between these genotypes produced some superiority hybrids. While, the lowest genetic distances found between P1 namely Sakha 1 and its hybrids. Results of genetic distances between these genotypes were high of results were obtained by Basheer-Salimia et al. (2013) revealed that the genetic distance ranged from 0.069 to 0.358 , with an average 0.213 . And Dora et al. (2017) reported genetic distance ranged from 0.099 to 0.556 on the basis of RAPD and SSR combined data among four faba bean genotypes and their seven $F_{2}$ bulks. The highest value indicates that the two genotypes are distantly related. While, the lowest value illustrate that there is high similarity between both genotypes which might be produced from related parents. Results in harmony with those of Diers et al. (1996) and Vajire et al. (2017) who illustrated that parents with a long genetic distance can produce a hybrid with better yield performance.

Dendrogram of the five faba bean cultivars and their twenty hybrids are divided into five clusters are shown in Fig. 1. The first cluster contains seven genotypes; P1, P2 and five hybrids. The second cluster contains three hybrids, the third cluster was considered the largest one which contains eleven genotypes was divided into two sub clusters: One of them contain four genotypes; P3 cultivar and three hybrids. The second sub cluster contains seven genotypes; P4, P5 and five hybrids. The fourth and fifth clusters each of them contain two hybrids. These results indicated that genetic variability was found between some studied genotypes of faba bean by using RAPD markers technique, These results are in agreement those of with Tanttawi et al. (2007) and Obiadalla-Ali et al. (2015) who reported that RAPD markers and agronomic characterizations will be useful tools for assessing the genetic diversity and understanding the breeding patterns of faba bean consequently, obtaining on Hybrid progeny of stable parents exhibited stability for its traits. 


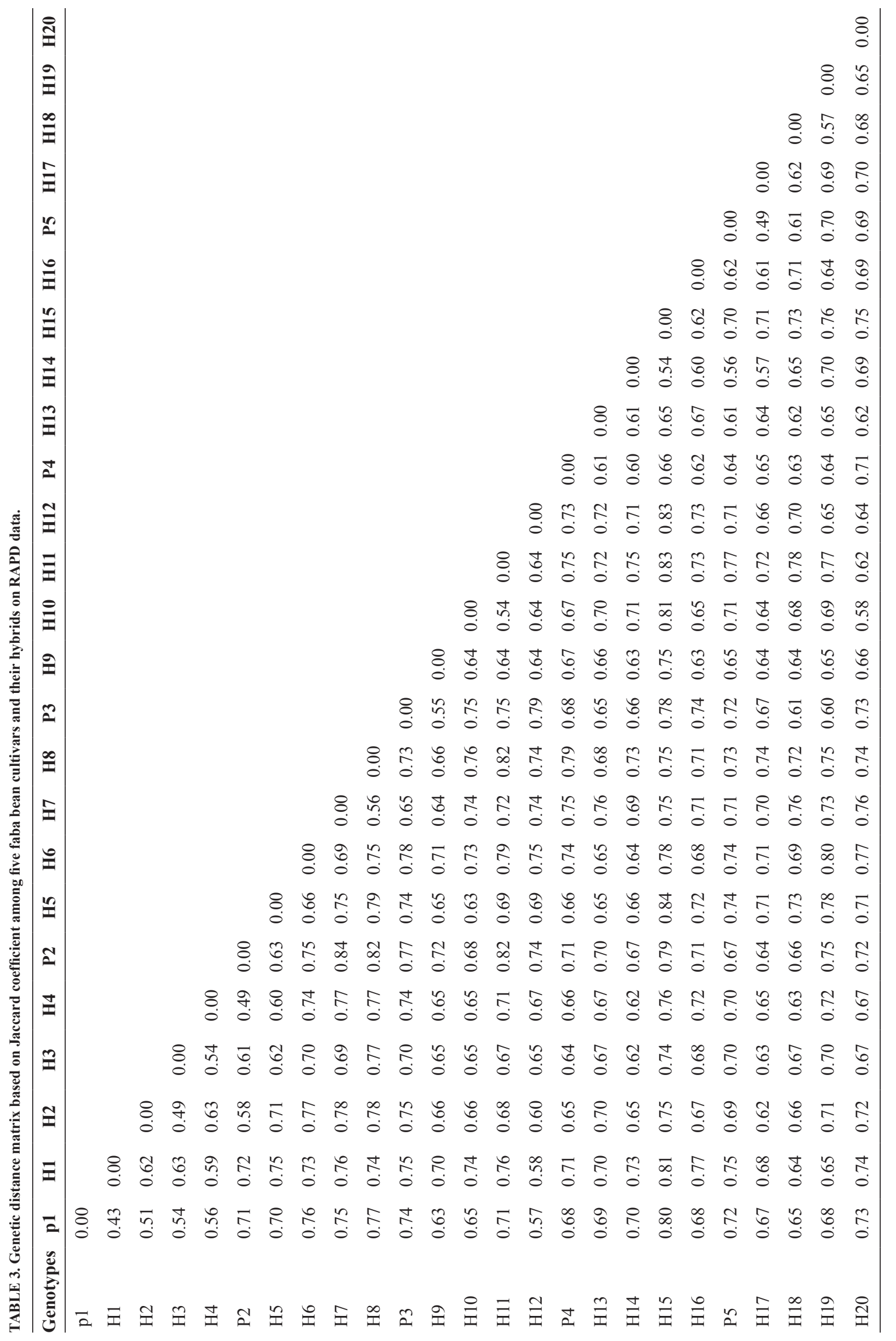

Egypt. J. Agron. 40, No.3 (2018) 


\section{Rescaled Distance Cluster Combine}

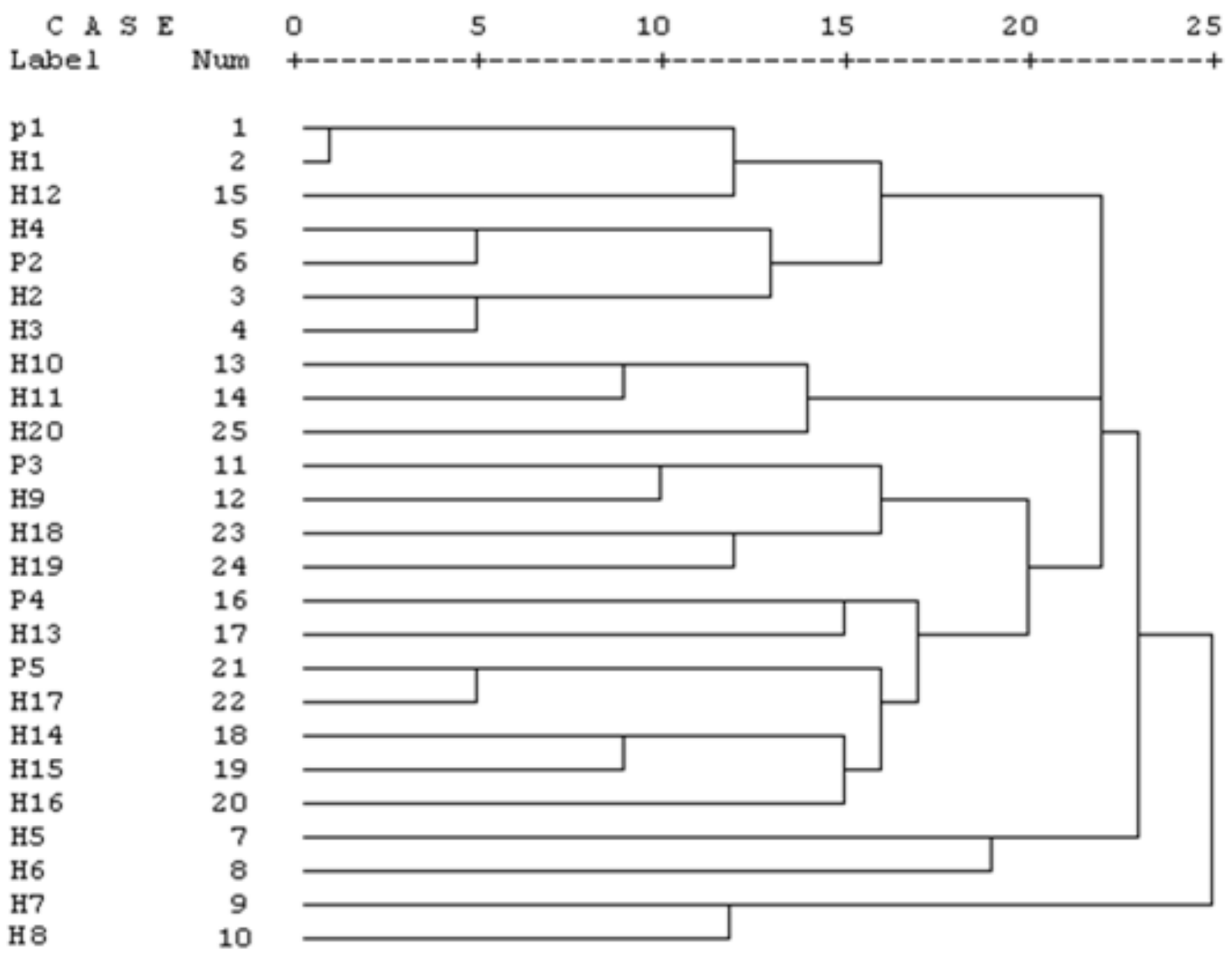

Fig. 1. Dendrogram of five cultivars of faba bean and their hybrids based on average of genetic distances among genotypes.

\section{Agronomy traits}

Mean values of yield components traits were used to determine the Euclidean distances and relations between the studied genotypes of faba bean (Table 4). The results showed Euclidean distance value ranged from 0.00 to 1.00 . The lowest Euclidean distance was found between (H8 and P4), (H14 and H17) and (H14 and H15) hybrids, which it have long distance between each other. Moreover, these hybrids have long distance between them and all studied genotypes. These results refer to large amount of variations are found between these hybrids. Results were in agreement with those of Obiadalla-Ali et al. (2015) who illustrated that the range of Euclidean distance among the genotypes was relatively wide and reflect the genetic diversity of the genes controlling these characters. The number of clusters and the intercluster distances indicated presence of significant genetic diversity in the genotypes under study (Kumar et al., 2016).
Clusters based on Euclidean distances (Fig. 2) divided genotypes for five clusters. The first cluster contain thirteen genotypes and it divided into two sub clusters; one of them contain seven genotypes and the rest contained three genotypes. The second cluster contained P1 cultivar, the third cluster contained nine genotypes and it divided into two sub clusters; one of them contained three genotypes and the last contain six genotypes, while, the fourth and fifth clusters each of them contain one hybrid. These results were nearly to the results based on RAPD analysis but there were some differences between them.

The difference between genetic distances based on RAPD analysis and Euclidean distances based on mean values of agronomy traits may due to environmental conditions, because agronomy traits are sensitive for it while DNA is stable. RAPD markers were more polymorphic than agro-morphological characterization, but 
when the RAPD markers combined with agromorphological characterization provided the most potent assay for selective genetic diversity (Khaled et al., 2014). Genetic distance measured by RAPD and yield component can be used as a guide to select the superiority crosses (Xiao et al., 1996 and Dias et al., 2003). Cluster analysis was highly significant correlation based on AFLP analysis with agro-morphological characters ( $\mathrm{r}=$ $0.26, \mathrm{P}<0.004$ ) (Ammar et al., 2015). These results in harmony by Obiadalla-Ali et al. (2015) who found a positive, but non-significant, correlation $(\mathrm{r}=0.085)$ between Euclidean distance and RAPD distance was observed.

\section{Heterosis}

Heterosis defined as the difference between trait expression of this $F_{1}$ hybrid and the average of its homozygous parents. Heterosis has been interpreted to reflect gene action other than additive (Crow, 2000 and Abdalla et al., 2017). The level of heterosis exhibited by hybrids is directly related with the genetic distance between their parental lines. The percentage of heterosis relative to the mid parents for yield and yield components traits are presented in Table 5 . Results showed that some crosses had positive and significant values of heterosis percent. While, another type of crosses had negative significant heterosis; H13, H17 and H18 hybrids from twenty have positive and significant values of heterosis of mid parents for all studied traits. Also, H19 and H20 hybrids have positive and significant values of heterosis of mid parents for all studied traits except, 100 seed weight trait which has negative and significant heterosis value percent. Results of heterosis percent showed H1, H9, H10 and $\mathrm{H} 17$ are superiority hybrids; they have vigor of heterosis on 100 seeds weight, pods number/plant, weight of pods/plant, plant height and weight of seeds/plant over their parents, although H1, H9 and $\mathrm{H} 10$ hybrids have negative values like; $\mathrm{H} 1$ and $\mathrm{H} 10$ have negative value of heterosis for weight of seeds/plant, also H9 and H10 have negative value of heterosis for pods weight/plant. Hybrids are involved in novel allelic interactions which caused change of gene expression and that the variation for the existence or absence of genes helps to produce heterotic phenotypes (Springer \& Stupar, 2007). Various crosses combinations showed different degrees of $F_{1}$ superiority in some yield and growth traits based on the genes in parental combinations that may add directly or indirectly to the traits (Yamani, 2012). The superiority of hybrids over the mid parents for seed yield is associated with the manifestations of the heterotic effects for yield component traits (El-Hady et al., 2007).

These results agree with Ibrahim (2010) and Obiadalla-Ali et al. (2013) who reported $\mathrm{F}_{1}$ hybrids in most crosses have significant percentage of heterosis for most traits of faba bean. Also, in harmony by Dieckmann \& Link (2010) who reported the quantitative genetic analysis showed an average of $10.6 \%$ mid-parent heterosis for mature seed weight and $14.5 \%$ midparent heterosis for juvenile biomass. $\mathrm{H} 1$ and $\mathrm{H} 10$ hybrids had positive significant heterosis for all traits except, seed weight/plant trait either more pods weight/plant for H10 hybrid only. While, another group of crosses; H4, H14, H15 and H16 had negative and significant values of heterosis over mid parents in most studied traits might due to the effect of P4 (Giza 3) in these crosses which have low values of yield and yield component traits. These results agree with Saad et al (2015) and Abdalla et al. (2017) who found significant positive and negative heterosis, insignificant positive and negative heterosis in plant height, branch number/plant, significant positive heterosis in number of pods per plant and significant negative heterosis in 100 seed weight. Positive or negative significant heterosis might due to the dominance and over dominance hypothesis and/ or epistasis (Crow, 1999, 2000; Frascaroli et al., 2007 and Lee et al., 2007). Reviewed that positive and significant heterosis over mid-parent parent is exhibited by $F_{1}$ faba bean hybrids for plant height, branches number per plant, number of pods per plant and seeds per plant, seed yield and 100 -seed weight which varied according to cross combinations and trait (Bishnoi et al., 2012 and Abdalla et al., 2017). Most crosses that include P5 (Giza 843), P1 (Sakha 1) and/or P2 (Sakha 3) have the highest and significant positive percentage of heterosis; so it can considered them the best general combiner. This finding agrees with that reported by Obiadalla-Ali et al. (2015) and Abdalla et al. (2017) who consider Giza 843 cultivar of faba bean as the best general combiner for branch number/ plant and 100 seeds weight traits. Parents from divergent clusters can be used for hybridization in order to isolate useful recombinants in the segregating generations (Tsegaye et al., 2012). This information might be used in the genetics and breeding programs for improvement. The results of heterosis percentage were in harmony with the results of RAPD analysis and Euclidean distance. 


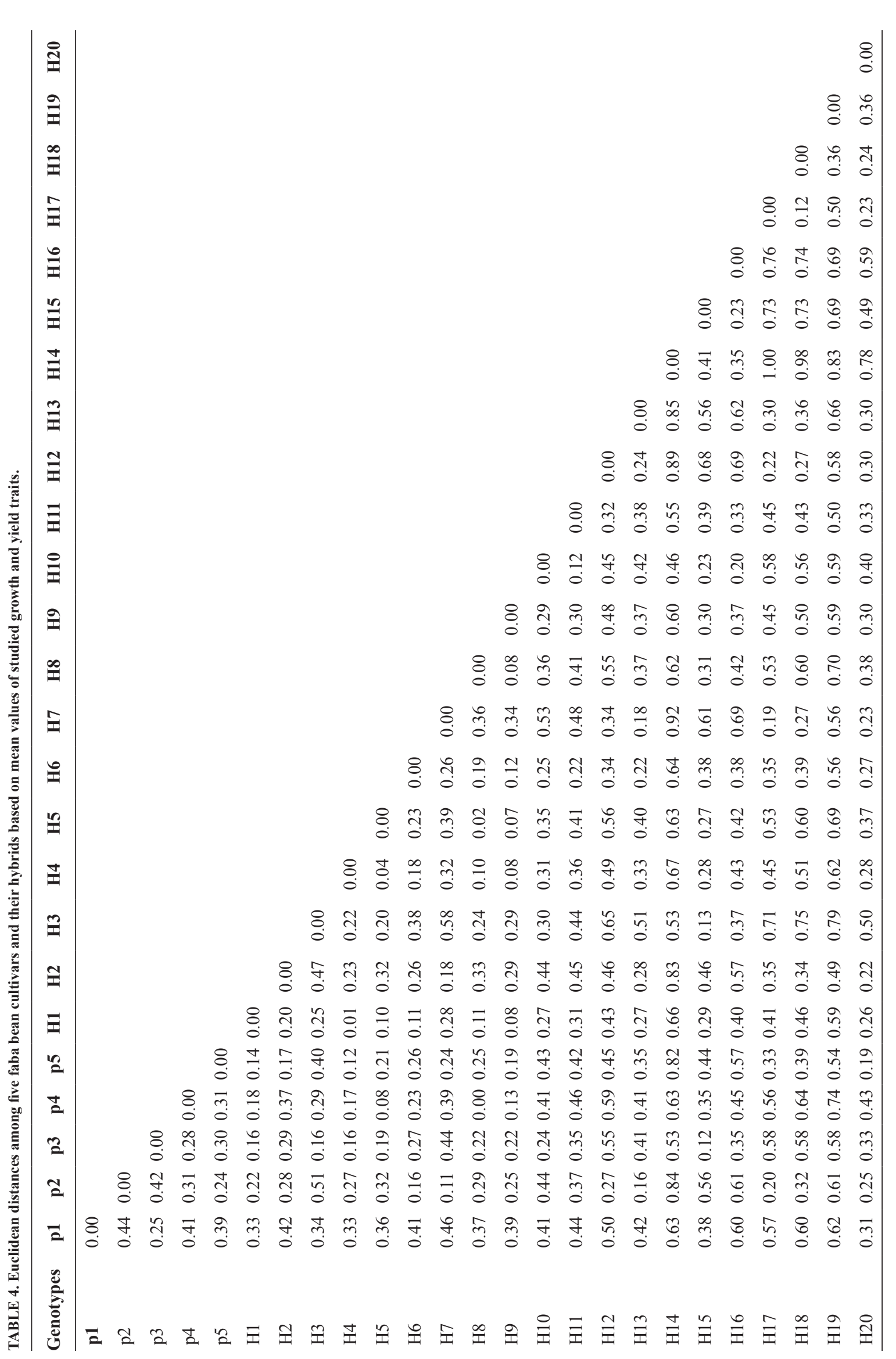


Rescaled Distance Cluster Combine

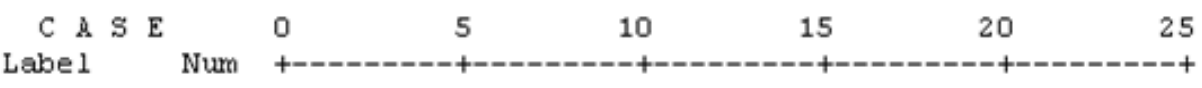

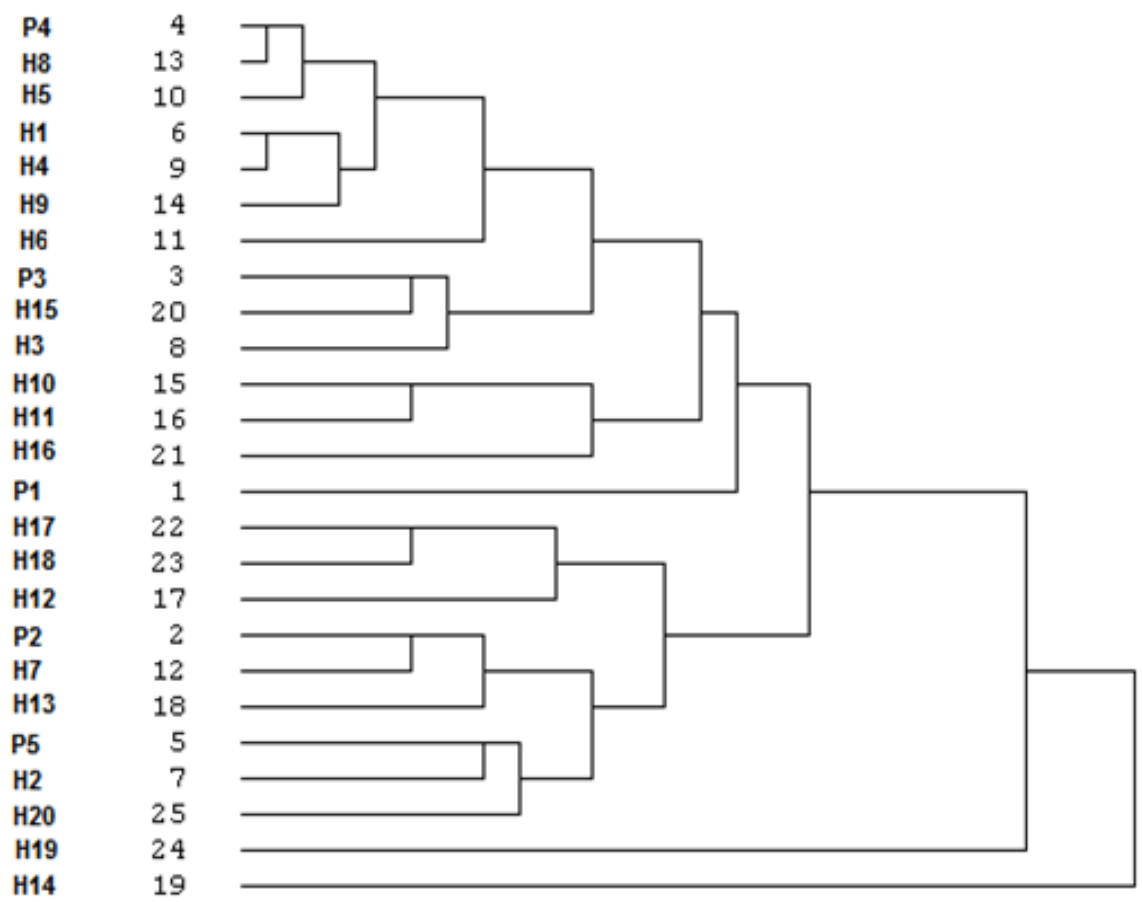

Fig. 2. Dendrogram UPGMA cluster analysis showing the Euclidean distances among twenty five genotypes of faba bean based on mean values of all studied yield and yield component traits.

TABLE 5. Heterosis of mid parents for yield and yield component traits of faba bean hybrids.

\begin{tabular}{|c|c|c|c|c|c|c|}
\hline Genotypes & Plant height. & Branch number & Pods number & $\begin{array}{c}\text { Weight of pods/ } \\
\text { plant }\end{array}$ & $\begin{array}{c}\text { Seeds weight / } \\
\text { plant }\end{array}$ & 100 seeds weight \\
\hline $\mathrm{H} 1$ & $18.8^{* *}$ & 14.3 & $20.0^{* *}$ & $25.5^{* *}$ & $-4.7^{* *}$ & $38.7^{* *}$ \\
\hline $\mathrm{H} 2$ & $-4.4^{* *}$ & -14.3 & $56.2^{* *}$ & $11.4^{* *}$ & $-1.7^{* *}$ & $27.0^{* *}$ \\
\hline $\mathrm{H} 3$ & $8.3^{* *}$ & 0.0 & $-43.2^{* *}$ & $-27.3^{* *}$ & $-25.8^{* *}$ & 0.0 \\
\hline $\mathrm{H} 4$ & $-10.1^{* *}$ & 0.0 & $-12.4^{* *}$ & $-17.9^{* *}$ & $-13.7^{* *}$ & $16.7^{* *}$ \\
\hline H5 & $10.0^{* *}$ & 0.0 & $7.5^{*}$ & $5.7^{* *}$ & $-4.7^{* *}$ & $41.2^{* *}$ \\
\hline H6 & $-3.4^{* *}$ & $25.0^{*}$ & $13.7^{* *}$ & $7.4^{* *}$ & $6.4^{* *}$ & $13.9^{* *}$ \\
\hline $\mathrm{H} 7$ & $6.7^{* *}$ & -12.5 & $25.0^{* *}$ & $23.5^{* *}$ & $0.9^{* *}$ & $-10.7^{* *}$ \\
\hline H8 & $1.6^{*}$ & 14.3 & $-20.7^{* *}$ & $-5.3^{* *}$ & $-7.9^{* *}$ & $16.8^{* *}$ \\
\hline H9 & $1.8^{*}$ & $28.6^{* *}$ & $64.4^{* *}$ & $-4.0^{* *}$ & $39.1^{* *}$ & $59.6^{* *}$ \\
\hline $\mathrm{H} 10$ & $16.1^{* *}$ & $50.0^{* *}$ & 1.1 & $-17.8^{* *}$ & $-7.8^{* *}$ & $75.5^{* *}$ \\
\hline H11 & $3.1^{* *}$ & $50.0^{* *}$ & $28.1^{* *}$ & $-8.0^{* *}$ & $17.2^{* *}$ & $-12.6^{* *}$ \\
\hline H12 & -0.2 & $57.1^{* *}$ & 3.8 & $41.2^{* *}$ & $54.5^{* *}$ & $-5.9^{* *}$ \\
\hline H13 & $10.6^{* *}$ & $28.6^{* *}$ & $8.1^{*}$ & $46.9^{* *}$ & $16.4^{* *}$ & $12.9^{* *}$ \\
\hline H14 & $3.8^{* *}$ & $75.0^{* *}$ & -4.2 & $-54.6^{* *}$ & $-50.5^{* *}$ & $-30.4^{* *}$ \\
\hline H15 & -1.0 & 0.0 & $-21.3^{* *}$ & $-38.1^{* *}$ & $-37.9^{* *}$ & $-21.0^{* *}$ \\
\hline H16 & $-17.2^{* *}$ & $42.9^{* *}$ & $-18.1^{* *}$ & $-46.9^{* *}$ & $-52.8^{* *}$ & $-20.5^{* *}$ \\
\hline H17 & $20.7^{* *}$ & $66.7^{* *}$ & $95.5^{* *}$ & $79.2^{* *}$ & $72.7^{* *}$ & $52.0^{* *}$ \\
\hline H18 & $33.2^{* *}$ & $57.1^{* *}$ & $83.8^{* *}$ & $51.6^{* *}$ & $27.3^{* *}$ & $9.2^{* *}$ \\
\hline H19 & $17.6^{* *}$ & $57.1^{* *}$ & $144.2^{* *}$ & $37.5^{* *}$ & $19.7^{* *}$ & $-15.6^{* *}$ \\
\hline $\mathrm{H} 20$ & $25.7^{* *}$ & $28.6^{* *}$ & $48.6^{* *}$ & $26.9^{* *}$ & $23.0^{* *}$ & $-16.3^{* *}$ \\
\hline
\end{tabular}

*Significant at $5 \%, * *$ significant at $10 \%$ 


\section{Conclusion}

Using molecular markers techniques identified the variations and facilitate the selection of distinguished genotypes which have useful traits in breeding programs, although some hybrids have positive significant heterosis, there are a lot of difficulties in its production. So, there is a need to produce such hybrids on commercial scale.

\section{References:}

Abdalla, M.M.F., Shafik, M.M., Attia, S.M. and Ghannam, H.A. (2017) Heterosis, GCA and SCA effects of Diallel-cross among six faba bean (Vicia faba L.) genotypes. ARJA, 4(4), 1-10, Article no.ARJA.32291.

Abdel Sattar, A.A. and El-Mouhamady, A.A. (2012) Genetic analysis and molecular markers for yield and its component traits in faba bean (Vicia faba L.) Aust. J. Basic \& Appl. Sci. 6(7), 458-466.

Alghamdi, S.S. (2009) Varietal identification and genetic purity assessment of F 1 hybrid seeds using RAPD markers in faba bean (Vicia faba L.). ISHS Acta Horticulturae No. 829, 269-274.

Ammar, M.H., Alghamdi, S.S., Migdadi, H.M., Khan, M.A., El-Harty, E.H. and Al-Faifi, S.A. (2015) Assessment of genetic diversity among faba bean genotypes using agro-morphological and molecular markers. Saudi J. of Bio. Sci. 22, 340-350.

Basheer-Salimia, R., Shtaya, M., Awad, M., Abdallah, J. and Hamdan, Y. (2013) Genetic diversity of Plastine landraces of faba bean (Vicia faba L.) based on RAPD markers. Genetic and Molecular Research, 12(3), 3314-3323.

Bishnoi, S.K., Hooda, J.S., Yadav, I.S. and Panchta, R. (2012) Advances in heterosis and hybrid breeding in faba bean (Vicia faba L.). Forage Res. 38, 24-27.

Crow, J.F. (1999) Dominance and overdominance. In: "Genetics and Exploitation of Heterosis in Crops", Coors, J.G., Pandey, S. (Ed.), pp 49-58. American Society of Agronomy, Madison, WI.

Crow, J.F. (2000) The rise and fall of overdominance. In: "Plant Breeding Reviews", pp. 225-257.

Dias, L.A.D.S., Marita, J., Cruz, C.D., Barros, E.G. and Salomao, T.M.F. (2003) Genetic distance and its association with heterosis in cacao. Brazilian Archives of Biology and Technology J. 46(3), 339347.

Dieckmann, S. and Link, W. (2010) Quantitative genetic analysis of embryo heterosis in faba bean (Vicia faba L.). Theor. Appl. Genet. 120, 261-270.

Diers, B.W., Mcvetty, P.B.E. and Osbom, T.C. (1996) Relationship between heterosis and genetic distance based on RFLP markers in oilseed rape (Brassica napus L.). Crop Sci. 36, 79-83.

Dora, S.A., Rady, M.M., Abou-Shosha, A.A., Aboulila, A.A. and Kalboush, S.F.A. (2017) Nature of gene action and efficiency of molecular markers for evaluation of genetic polymorphism for orobanche tolerance in Faba Bean (Vicia faba L.). J.Agric. Chem. Biotechn. Mansoura Univ. 8(2), 47-56.

El-Hady, M.M., Rizk, A.M.A., Omran, M.M. and Ragheb, S.B. (2007) Genetic behavior of some faba bean (Vicia faba L.) genotypes and its crosses. Ann. Agric.Sci. 45, 49-60.

Frascaroli, E., Cane, M.A., Landi, P., Pea, G., Gianfranceschi, L., Villa, M., Morgante, M. and Pe', M.E. (2007) Classical genetic and quantitative trait loci analyses of heterosis in a maize hybrid between two elite inbred lines. Genetics, 176, 625-644.

Goodman, M.M. (2004) Plant breeding requirements for applied molecular biology. Crop Sci. 44, 1913-1914.

Hayman, B.I. (1958) The theory and analysis of diallel crosses 1. Genetics, 39, 789-809.

Ibrahim, H.M. (2010) Heterosis, combining ability and components of genetic variance in faba bean (Vicia faba L.). JKAU: Met. Environ Arid Land Agric. Sci. 21(1), 35-50.

Jaccard, P. (1908) Nouvelles recherches sur la distribution florale. Bull. Soc. Vaud. Sci. Nat. 44, 223-270.

Johnson, P.L., Sharma, R.N. and Nanda, H.C. (2015) Genetic diversity and association analysis for yield traits chickpea (Cicer arietinum) under rice based cropping system. The Bioscan. 10(2), 879-884.

Johnson, G.R. and Mccuddin, Z.P. (2009) Maize and the biotech industry. In: "Handbook of Maize: Its Biology,"Bennetzen, J.L. and Hake, S.C. (Ed.), pp. 115-140. Springer: Berlin, Germany. 
Khaled, A.G.A., Tag El-Din, A.A. and Hussein, E.M. (2014) Correlation, path analysis and RAPD markers in sorghum (Sorghum bicolor L. moench) genotypes. Assiut J. Agric. Sci. 45(4), 15-28.

Kumar, P., Hooda, J.S., Singh, B., Sharma, P. and Bishnoi, S.K. (2016) Genetic diversity and relationship study in faba bean (Vicia faba L.). Genotypes of indian and exotic origin. An Int. Quarterly J. Life Sci. 11(3), 2003-2006.

Laghetti, G., Pignone, D. and Sonnante, G. (2008) Statistical approaches to analyse gene bank using lentil germplasm collection as a case study. Agri. Constr. Sci. 73, 175-81.

Lee, E.A., Ash, M.J. and Good, B. (2007) Re-examining the relationship between degree of relatedness, genetic effect, and heterosis in maize. Crop Sci. 47, 629-635.

Moose, S.P. and Mumm, R.H. (2008). Molecular plant breeding as the foundation for $21^{\text {st }}$ century crop improvement. Plant Physiol. 147, 969-977.

Obiadalla-Ali, H.A., Mohamed, N.E.M., Glala, A.A.A. and Eldekashy, M.H.Z. (2013) Heterosis and nature of gene action for yield and its components in faba bean (Vicia faba L.). J. Plant Breed Crop Sci. 5(3), 34-40.

Obiadalla-Ali, H.A., Mohamed, N.E. and Khaled, A.G. (2015) Inbreeding, outbreeding and RAPD markers studies of faba bean (Vicia faba L.). Crop. J. Adv. Res. 6(6), 859-868.

Poresbski, S.L., Bailey, G. and Baum, R.B. (1997) Modification of CTAB DNA extraction protocol for plants containing high polysaccharide and polyphenol components. Plant Mol. Biol. Rep. 12, 8-15.

Saad, E., Zaghloul, H. and Pasha, A.S. (2015) Assessment of heterosis and features of gene activity for yield and its components in faba bean (Vicia faba L.). Int. J. Agril. Sci. 5, 676-681.

Shekhawat, U.S., Vijay, P. and Singhania, D.L. (2001) Genetic divergence in barley (Hordeum vulgare L.). Indian J. Agric. Res. 35(2), 121-123.

Sneath, P.H.A. and Sokal, R.R. (1973) "Numerical Taxonomy". W.H. Freeman \& Co., San Francisco.
Springer, N.M. and Stupar, R.M. (2007) Allelic variation and heterosis in maize: How do two halves make more than a whole. Genome Res. 17, 264-275.

SPSS (1995) SPSS user's guide. SPSS.Inc. USA.

Tahir, N.A. (2015) Identification of genetic variation in some faba bean (Vicia faba L.) genotypes grown in Iraq estimated with RAPD and SDS-PAGE of seed proteins. Ind. J. Biotech. 14, 351-356.

Tanttawi, D.M., Khaled, A.G.S. and Husni, M.H. (2007) Genetic studies for some agronomic characters in faba bean (Vicia faba L.). Assiut J. Agric. Sci. 38(4), 117-137.

Tiwari, A. (2017) Plant Breeding: A Prospect in Developing World. EC Microbiology, 8(5), 272-278.

Tsegaye, D., Dessalegn, T., Dessalegn, Y. and Share, G. (2012) Analysis of genetic diversity in some durum wheat (Triticum durum Desf) genotypes grown in Ethiopia. Afr. J. Biotechnol. 11(40), 9606-9611.

Vajire, D., Thakare, K., Solunke, R., Panche, A. and Tiwari, A. (2017) The possibilities of the prediction of heterosis in elite lines of onion based on the assessment of genetic diversity. Ec Microbiology, 10(5), 211-219.

Xiao, J., Li, J. , Yuan, L., Mccouch, S.R. and Tanksley, S.D. (1996) Genetic diversity and its relationship to hybrid performance and heterosis in rice as revealed by PCR-based markers. Theor. Appl. Genet. 92, $637-$ 643.

Yahia, Y., Hannachi, H. and Ferchichi, A. (2014) Genetic diversity of Vicia faba L. based on random amplified polymorphic DNA and simple sequence repeat markers. Acta Botanica Gallica: Botany Letters, 161(2), 151-158.

Yamani, Kh.M.M. (2012) Heterosis and combining ability in F1 and F2 of faba bean (Vicia faba L.) Assiut J. of Agric. Sci. 43(4), 49-62. 


\title{
التنوع الوراثى بين هجن الفول البلاى و علاقته بقوة الهجين باستخدام القياسات الجزيئية

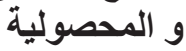 \\ أمل محمد عبد المجيد \\ قسم النبات الزر اعى ــ كلية الزاعة - جامعة قناة السويس - الإسماعيلية ـ مصر.
}

\begin{abstract}
استخدم التنوع الور اثى فى الحصول على قوة الهجين. حيث تم اجراء التهجين بين خمسة أصناف مصرية من الفول

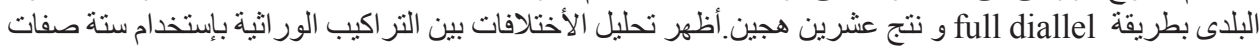

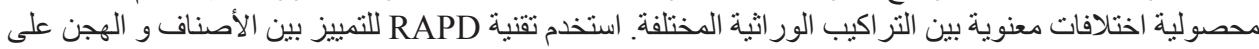

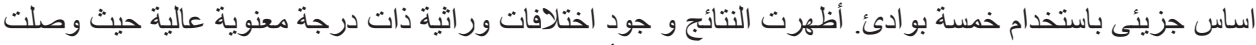

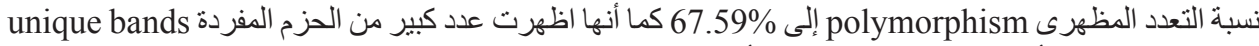

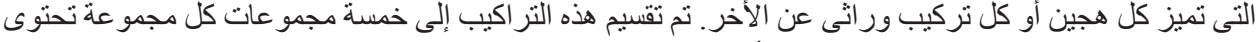

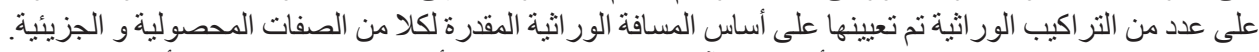

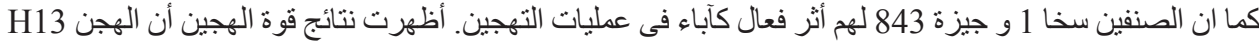

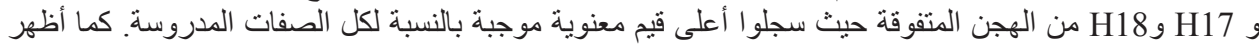
الهجين H19 و H20 قوة هجين عالية بالنسبة لكل الصفات ماعدا صفة وزن ال مال 100 بذرة.
\end{abstract}

